\title{
FAKTOR PERSALINAN DAN KEJADIAN ASFIKSIA DI RSUD KOTA BOGOR
}

\author{
Fauzia, Sri Wahyuni \\ Poltekkes Kemenkes Bandung, Jl. Pajajaran No.56 Bandung \\ Email: zakiayuwafa@yahoo.com
}

Asphyxia Neonatorum's Frequency in Bogor City

\begin{abstract}
Asphyxia neonaturum is a condition in newborns who have failed to breathe spontaneously and regularly soon after birth. The condition of labor that can cause asphyxia neonatorum is delivery with a breech, the long or jammed delivery process and labor with premature rupture of membranes. The research design were sequential explanatory mixed method research by using quantitative data analysis in the first stage, followed by qualitative data collection. Research will be conducted in Bogor City Hospital. When the study is the month from January to November 2016. The sample collection used simple random sampling technique. The results of the study there is no influence breech birth with asphyxia $(p=0.103)$, obstructed labor or jammed with asphyxia $(p=0.452)$ and premature rupture of membranes with asphyxia $(p=0.809)$
\end{abstract}

Keywords: asphyxia, delivery factor

\begin{abstract}
Abstrak: Asfiksia neonaturum adalah suatu keadaan bayi baru lahir yang mengalami gagal bernafas secara spontan dan teratur segera setelah lahir. Kondisi persalinan yang dapat menyebabkan asfiksia neonaturum adalah persalinan dengan sungsang, proses persalinan lama/macet serta persalinan dengan ketuban pecah dini. Penelitian ini adalah penelitian dengan desain penelitian sequential explanatory mixed methode dengan menggunakan analisis data kuantitatif pada tahap pertama,diikuti oleh pengumpulan data kualitatif. Penelitian akan dilakukan di RSUD Kota Bogor. Waktu penelitian yaitu bulan Januari hingga November 2016. Pengambilan sampel dengan cara simple random sampling. Hasil penelitian tidak terdapat pengaruh persalinan letak sungsang dengan asfiksia $(p=0,103)$, partus lama atau macet dengan asfiksia $(p=0,452)$ dan ketuban pecah dini dengan asfiksia $(p=0,809)$
\end{abstract}

Kata Kunci: asfiksia, faktor persalinan

\section{PENDAHULUAN}

Menurut WHO, setiap tahunnya kira-kira $3 \%$ (3,6 juta) dari 120 juta bayi lahir mengalami asfiksia, hampir 1 juta bayi ini kemudian meninggal dunia. Di Indonesia dari seluruh kematian bayi, sebanyak $57 \%$ meninggal pada masa bayi baru lahir (usia dibawah 1 bulan), sehingga diestimasikan setiap 6 menit terdapat satu bayi meninggal (JNPK-KR, 2008).

Angka kematian bayi (AKB) di Indonesia sekarang masih tinggi yaitu 34 per 1000 kelahiran hidup. Hal ini masih jauh dari target MDGs yang harus dicapai pada tahun 2015 sebesar 24 per 1000 kelahiran hidup (BAPPENAS, 2010). Penyebab kematian bayi baru lahir (BBL) di Indonesia sendiri terbesar kedua adalah asfiksia yaitu sebesar $27 \%$ (JNPK$\mathrm{KR}, 2008$ ).

Di kota Bogor, tingginya angka persalinan oleh tenaga kesehatan rata rata $10 \%$ dari jumlah seluruh persalinan. Rendahnya cakupan persalinan oleh tenaga kesehatan berdampak pada tingginya kejadian komplikasi pada ibu dan bayi yaitu 3\% kejadian komplikasi pada bayi dan $10 \%$ kejadian komplikasi pada ibu. Pada tahun 2015 ditemukan angka kematian neonatus sebanyak 51 orang, terdiri dari pasien BBLR 18 orang, Asfiksia 19 orang, Sepsis 2 orang, kelainan kongenital 5 orang,dan lainnya 7 orang. Kejadian kematian neonatus ini sangat berkaitan dengan kualitas pelayanan kesehatan.

Asfiksia neonaturum adalah suatu keadaan bayi baru lahir yang mengalami gagal bernafas 
secara spontan dan teratur segera setelah lahir, sehingga bayi tidak bisa memasukkan oksigen dan tidak dapat mengeluarkan zat asam arang dari tubuhnya (Dewi, 2010). Kondisi persalinan yang dapat menyebabkan asfiksia neonaturum adalah persalinan dengan ketuban pecah dini, persalinan sungsang, serta proses persalinan lama/ macet.

Ketuban pecah dini adalah dimana ketuban pecah sebelum proses persalinan berlangsung (YBP-SP, 2006). Walaupun ibu belum menunjukkan gejala-gejala infeksi tetapi janin mungkin sudah terkena infeksi, karena infeksi intrauterin lebih dahulu terjadi (amnionitis, vaskulitis) sebelum gejala pada ibu dirasakan. Hal ini akan meninggikan morbiditas bayi salah satunya adalah asfiksia.

Persalinan sungsang merupakan persalinan dimana janin terletak memanjang dengan kepala di fundus uteri dan bokong berada di bagian bawah kavum uteri. Persalinan sungsang mempunyai resiko kematian perinatal langsung sebesar 4-5 kali dibanding presentasi kepala. Sebab kematian perinatal pada persalinan presentasi sungsang ini salah satunya adalah hipoksia atau perdarahan di dalam tengkorak yang berakibat bayi lahir dengan asiksia (Manuaba, 2009).

Persalinan yang berlangsung lama (partus lama) yaitu persalinan yang mengakibatkan gangguan pertukaran gas dan transportasi oksigen sehingga bayi mengalami asfiksia yang progresif, kontraksi rahim yang terjadi pada saat inpartu menyebabkan aliran oksigen ke plasenta berkurang sehingga setelah bayi lahir akan menunjukkan gejala seperti tubuh bayi kebiruan (sianosis), tonus otot berkurang (Wiknjosastro, 2007).

Manifestasi asfiksia neonaturum dalam pelayanan kebidanan adalah dengan melakukan penilaian Apgar Skore. Penilaian Apgar skore adalah akumulasi dari penilaian warna kulit, frekwensi jantung, reaksi terhadap rangsangan, tonus otot dan pernafasan. Nilai Apgar pada umumnya dilaksanakan pada I menit dan 2 menit sesudah bayi lahir. Tapi penilaian harus dimulai segera sesudah bayi lahir. Apabila bayi memerlukan intervensi berdasarkan penilaian pernapasan, denyut jantung atau warna kulit maka penilaian ini harus dilakukan segera.

Hasil dari penilaian Apgar skore tersebut menunjukkan derajat vitalitas fungsi tubuh bayi. Derajat vitalitas adalah kemampuan sejumlah fungsi tubuh yang bersifat esensial dan kompleks untuk kelangsungan hidup bayi. Derajat vitalitas bayi dapat dipengaruhi oleh banyak faktor diantaranya adalah faktor ibu, bayi dan persalinan.

Tujuan penelitian ini adalah untuk mengetahui pengaruh faktor persalinan dengan kejadian asfiksia neonatorum di Kota Bogor.

\section{METODE PENELITIAN}

Desain penelitian adalah sequential explanatory mixed methode dengan menggunakan analisis data kuantitatif pada tahap pertama, diikuti oleh pengumpulan data kualitatif. Penelitian dilakukan di RSUD Kota Bogor. Waktu penelitian yaitu bulan Januari hingga November 2016. Pengambilan sampel dengan cara simple random sampling dimana dengan melihat dokumentasi persalinan tahun 2015, apakah pernah terjadi asfiksia atau tidak

Tabel 1. Distribusi Frekuensi Subyek Penelitian

\begin{tabular}{lcc}
\hline Variabel & F & \% \\
\hline Asfiksia & & \\
Asfiksia & 39 & 39 \\
Tidak asfiksia & 61 & 61 \\
\hline KPD & & \\
KPD & 37 & 37 \\
Tidak KPD & 63 & 63 \\
\hline Sungsang & & \\
Sungsang & 4 & 4 \\
Tidak sungsang & 96 & 96 \\
\hline Partus lama & & \\
Partus lama & 10 & 10 \\
Tidak Partus lama & 90 & 90 \\
\hline
\end{tabular}


Tabel 2. Hubungan KPD, Persalinan Sungsang dan Partus Lama/Macet dengan Kejadian Asfiksia

\begin{tabular}{|c|c|c|c|c|c|}
\hline \multirow{2}{*}{ Variabel } & \multicolumn{2}{|c|}{ Asfiksia } & \multicolumn{2}{|c|}{ Tidak Asfiksia } & \multirow{2}{*}{$P_{\text {value }}$} \\
\hline & $\mathbf{n}$ & $\%$ & $\mathbf{n}$ & $\%$ & \\
\hline \multicolumn{6}{|l|}{ KPD } \\
\hline - KPD & 15 & 40,5 & 22 & 59,5 & \multirow[t]{2}{*}{0,809} \\
\hline -Tidak KPD & 24 & 38,0 & 39 & 62,0 & \\
\hline \multicolumn{6}{|l|}{ Sungsang } \\
\hline - Sungsang & 0 & 0 & 4 & 100 & \multirow[t]{2}{*}{0,103} \\
\hline - Tidak sungsang & 39 & 40,6 & 57 & 59,4 & \\
\hline \multicolumn{6}{|l|}{ Partus lama/macet } \\
\hline - Partus lama & 5 & 50,0 & 5 & 50,0 & \multirow[t]{2}{*}{0,452} \\
\hline -TidakPartus lama & 34 & 37,7 & 56 & 62,3 & \\
\hline
\end{tabular}

kemudian dievaluasi dari faktor persalinan yang meliputi KPD, sungsang dan partus lama/macet dengan asfiksia. Berdasarkan perhitungan, sampel yang didapat adalah 50 sampel, dengan mempertimbangkan effect design, maka sampel ditambah menjadi 100 sampel. Setelah data sekunder didapat, kemudian dilakukan wawancara mendalamuntuk mendapatkan hasil yang lebih akurat.

\section{HASIL PENELITIAN}

Berdasarkan data dari rekam medik rumah sakit yang diambil dari tanggal 24Agustus sampai dengan 1 November 2016. Subyek dalam penelitian ini adalah wanita yang masuk RSUD kota Bogor dan ingin bersalin. Jumlah responden yang ikut dalam penelitian sebesar 100 orang.

Analisis univariabel digunakan untuk menggambarkan distribusi frekuensi tentang asfiksia, dan faktor persalinan yang terdiri dari KPD, sungsang dan partus lama. Berdasarkan Tabel 1 dapat diketahui bahwa distribusi kejadian asfiksia pada responden sebagian besar responden melahirkan bayi yang tidak asfiksia yaitu 61 orang (61\%). Distribusi persalinan antara KPD dan tidak KPD dalam penelitian ini adalah ibu bersalin dengan KPD sebanyak 37 orang (37\%) dan responden untuk ibu bersalin dengan tidak KPD adalah 63 orang (63\%). Distribusi persalinan antara sungsang dan tidak sungsang dalam penelitian ini adalah ibu bersalin dengan sungsang sebanyak 4 orang (4\%) dan responden untuk ibu bersalin dengan tidak KPD adalah 96 orang (96\%). Distribusi persalinan antara Partus Lama dan tidak Partus lama dalam penelitian ini adalah ibu bersalin dengan Partus lama sebanyak 10 orang (10\%) dan responden untuk ibu bersalin dengan tidak Partus lama adalah 90 orang $(90 \%)$.

Hubungan KPD, persalinan sungsang dan partus lama/macet dengan kejadian asfksia di RSUD kota Bogor dapat dilihat di Tabel 2. Dari Tabel 2 dapat diketahui sebanyak 37 orang yang bersalin dan mengalami KPD melahirkan bayi yang sebagian besar tidak mengalami asfiksia neonatorum yaitu sebanyak 22 bayi $(59,5 \%)$ dan dari 63 orang yang bersalin dan tidak mengalami KPD melahirkan bayi yang sebahagian besar tidak mengalami asfiksia neonatorum yaitu sebanyak 39 bayi (62\%). Hubungan antara persalinan KPD dengan kejadian asfiksia dilihat dari hasil $p$ value sebesar 0,809 lebih besar dari 0,05 yang berarti tidak bermakna atau tidak ada hubungan antara persalinan KPD dengan kejadian asfiksia. Dari 4 orang yang bersalin dan mengalami sungsang melahirkan bayi yang seluruhnya tidak mengalami asfiksia neonatorum yaitu sebanyak 4 bayi $(100 \%)$ dan dari 96 orang yang bersalin dan tidak mengalami sungsang melahirkan bayi yang sebahagian besar tidak mengalami asfiksia neo- 
natorum yaitu sebanyak 57 bayi $(59,4 \%)$. Hubungan antara persalinan sungsang dengan kejadian asfiksia dilihat dari hasil $p$ value sebesar 0,103 lebih besar dari 0,05 yang berarti tidak bermakna atau tidak ada hubungan antara persalinan sungsang dengan kejadian asfiksia. Dari 10 orang yang bersalin dan mengalami partus lama atau macet melahirkan bayi yang tidak mengalami asfiksia neonatorum yaitu sebanyak 5 bayi (50\%) dan yang mengalami asfiksia neonatorum juga sebanyak 5 bayi (50\%) dan dari 90 orang yang bersalin dan tidak mengalami partus lama atau macet sebahagian besar tidak mengalami asfiksia neonatorum yaitu sebanyak 56 bayi $(62,3 \%)$

Hubungan antara persalinan partus lama/ macet dengan kejadian asfiksia dilihat dari hasil $\mathrm{p}$ value sebesar 0,452 lebih besar dari 0,05 yang berarti tidak bermakna atau tidak ada hubungan antara persalinan partus lama/macet dengan kejadian asfiksia.

\section{PEMBAHASAN}

Berdasarkan data rekam medik RSUD Kota Bogor yang diambil dari bulan Januari sampai bulan Desember 2016 diketahui bahwa tidak ada hubungan antara faktor persalinan (ketuban pecah dini, partus lama dan letak sungsang) dengan asfiksia. Hasil penelitian ini sejalan dengan penelitian Fatkhiyah (2008) yang menemukan bahwa sebagian besar ibu yang melahirkan di RSUD dr.Soesilo Tegal sebagian besar yaitu $64 \%$ tidak mengalami asfiksia. Bayi yang tidak mengalami asfiksia dapat mengurangi risiko jangka pendek seperti disfungsi organ tubuh seperti otak,paru,hati,ginjal,saluran cerna, dan sistem peredaran darah dan resiko jangka panjang seperti kerusakan hati, perdarahan, dan oedema paru (Manoe, 2013)

Berdasarkan hasil perhitungan secara statistik, tidak ada hubungan yang bermakna antara KPD, sungsang dan partus lama dimana angka $p$ value diatas 0,05 . Hal tersebut sejalan dengan Sandi (2011) yang mengatakan bahwa persalinan yang berjalan tidak normal karena adanya penyulit sering dilakukan sectio caesaria untuk mengurangi resiko kematian ibu dan perinatal. Pasien dengan rujukan mempunyai resiko 1,8 kali untuk mengalami persalinan dengan sectio caesaria daripada ibu yang datang sendiri.

Secara substansi tidak ada hubungan yang bermakna antara KPD, sungsang dan partus lama dimana angka $p$ value diatas 0,05 dianggap cukup bermakna, hal ini berdasarkan hasil wawancara peneliti dengan kepala pelayanan medik tidak adanya hubungan antara KPD, sungsang dan partus lama dengan asfiksia di RSUD Kota Bogor.

Berdasarkan hasil analisa tabulasi silang antara persalinan KPD dan kejadian asfiksia neonatorum didapatkan frekwensi terbesar pada ibu yang mengalami persalinan tanpa KPD dan bayi yang tidak mengalami asfiksia. Sejalan dengan penelitian Khanal (2009) yang meneliti kejadian KPD dengan kejadian asfiksia dimana $80 \%$ ibu yang diteliti tidak mengalami KPD dan terbebas dari kejadian asfiksia neonatorum.

Data lain yang dapat dilihat adalah kejadian ibu yang mengalami KPD namun bayinya tidak mengalami asfiksia sebesar 59,5\%. Hal ini sejalan dengan penelitian Linawati (2014) yang menyebutkan bahwa 68\% ibu yang KPD bayinya tidak mengalami asfiksia, sehingga tidak terdapat hubungan ibu yang bersalin dengan KPD. Menurut Depkes RI (2008) bahwa ketuban pecah dini merupakan faktor risiko terjadinya asfiksia neonatorum, didukung oleh Wiradharma (2012) yang menemukan bahwa ada hubungan antara kejadian asfiksia dan ibu yang mengalami ketuban pecah dini. Selain itu faktor ketepatan petugas dalam penanganan pasien bersalin juga mempengaruhi kejadian asfiksia. Pada penelitian Gilang et al (2010) didapatkan hasil bahwa pertolongan persalinan dengan letak sungsang, 
partus lama atau macet dan ketuban pecah dini berhubungan dengan terjadinya asfiksia neonatorum. Yulianti (2005) menyebutkan penatalaksanaan terakhir setelah dilakukan beberapa tahapan awal adalah sectio secaria sehingga angka kejadian neonatorum dapat dicegah. Sandi (2011) mengatakan bahwa pada kasus partus lama dan penyakit lainnya berdasarkan status rujukan bahwa kategori tidak asfiksia pada kelompok rujukan dan non rujukan merupakan proporsi terbesar $(76,9 \%$ dan $80,7 \%)$ dan kategori asfiksia merupakan proporsi terkecil (23, $1 \%$ dan $19,3 \%)$.

Tidak adanya hubungan tersebut diasumsikan karena adanya faktor ibu dan bayi yang belum teridentifikasi karena sistem dokumentasi yang masih terpisah antara status ibu dan bayi. Hal ini sejalan dengan hasil penelitian Aslam et al (2012) dalam penelitiannya tentang faktor risiko pada asfiksia neonatorum menjelaskan penyebab asfiksia neonatorum adalah dari faktor ibu dan faktor bayi. Dengan bertambah dan berkurangnya usia ibu, adanya KPD, multigravida, perdarahan antepartum, eklampsi, preeklampsi ikut berpengaruh terhadap terjadinya faktor risiko.

Faktor risiko yang besar salah satunya juga adalah ibu yang akan melahirkan dengan letak sungsang atau dengan CPD (Cephalopelvicdisproportion). Sebaiknya ibu dengan kondisi tersebut segera dibawa ke rumah sakit untuk dilakukan sectio secarea dan tidak ditolong oleh bidan di rumah. Letak sungsang mempunyai risiko 2,96 kali mengalami asfiksia neonatorum dibandingkan persalinan lain (Aslamet al, 2012).

\section{PENUTUP}

Kesimpulan dari penelitian ini diperoleh tidak terdapat hubungan yang bermakna antara persalinan KPD dengan asfiksia di RSUD Kota Bogor. Tidak terdapat hubungan yang bermakna antara persalinan sungsang dengan Asfiksia di
RSUD Kota Bogor. Tidak terdapat hubungan yang bermakna antara persalinan lama/macet dengan Asfiksia di RSUD Kota Bogor

Hal yang dapat direkomendasikan bagi RSUD Kota Bogor adalah perbaikan kualitas medical record agar terjadi kesinambungan antara status ibu dan bayi.

Bagi peneliti selanjutnya diharapkan melakukan penelitian dengan memperluas variabel bebas. Bisa diperluas untuk bisa diidentifikasi faktor ibu dan faktor bayi .

\section{DAFTAR PUSTAKA}

Arikunto, S., 2010. Prosedur Penelitian Suatu Pendekatan Praktek, Jakarta : PT.Rineka Cipta.

Azizah, Lilik Ma'rifatul. (2011). Keperawatan LanjutUsia. Yogyakarta: Graha Ilmu.

Aslam et al. 2012. Risk Factors of Birth Asphyxia, Italian Jurnal of Pediatric.

BAPPENAS, 2010, Laporan Pencapaian Tujuan Pembangunan Millenium Indonesia 2010

Cunningham FG et al.2005 Premature Rupture of the Membrane. Williams Obstetric, 22st ed. Mc.Graw Hill Publishing Division, New York

Darmojo, R. B. Martono, 2011. Geriatri (Ilmu Kesehatan Usia Lanjut Edisi ke, 4.

Depkes. 2008. Laporan Kesehatan Riset Kesehatan 2007

Depkes. 2008. Pencegahan dan Penatalaksanaan Asfiksia Neonaturum. Jakarta. Depkes RI

Dinkes Kota Bogor. (2015). Profil Kesehatan Kota Bogor, Bogor

Fatkhiyah, N. 2008. Hubungan Antara Kejadian Ketuban Pecah Dini dengan Kejadian Asfiksia Neonaturum di RSUD DR Soesilo Tegal Slawi: Stikes Bhamada

Friedman, M.M., Bowden, V.R., \& Jones,E.G. (2003). Family Nursing:Research Theory \& Practice. NewJersey: Prentice Hall. 
Gilang et al. 2010. Faktor-faktor yang berhubungan dengan kejadian asfiksia neonatorum (Studi di RSUD Tugurejo Semarang); FK Muhammadiyah Semarang.

Golubnitschaja, O. et al. 2011, Birth Asphyxia as The Major Complication in Newborn: moving towards Improved Individual Outcomes by Prediction, Targeted Prevention and Tailored Medical Care, EPMA Journal

Harry\&Forte,William R;1996.Ilmu Kebidanan Patologi \& Fisiologi.Jakarta, Yayasan Essentia Medica

Jumirah, 2015. Hubungan Persalinan Ketuban Pecah Dini dengan Kejadian Asfiksia Neonatorum di Rumah Sakit Panembahan Senopati Bantul, Skripsi, STIKES Aisyiyah Yogyakarta.

Khanal, S. 2009.A Comparatif Study of Outcome of Preterm Neonate with and Without History of PretermPremature of Membrane. Departement of Epidemiology, College of Public Health, China: Zhengzhou University.

Kresno Sudarti et al.1999. Aplikasi Penelitian Kualitatif dalam pencegahan dan pemberantasan Penyakit Menular, FKM UI, Depok Linawati.2014 Hubungan Kejadian KPD dengan Asfiksia BBL. STIKES Ahmad Yani Yogyakarta

Manoe, V. 2008. Gangguan Fungsi Multi Organ pada Bayi Asfiksia Berat. Jurnal Ilmu Kesehatan Anak FK UI, Jakarta

Manuaba, IG. 2009. Ilmu KebidananPenyakit Kandungan danKeluarga Berencana Untuk Pendidikan Bidan.Jakarta,EGC

Notoatmodjo, (2005), Metodologi Penelitian Kesehatan. Jakarta: Rineka Cipta

Nugroho, Wahjudi. (2012). Keperawatan Gerontik \& Geriatrik (Ed. 3). Jakarta: EGC
Orimo, H., Ito, H., Suzuki, T., Araki, A., Hosoi, T., \& Sawabe, M. (2006). Reviewing the definition of "elderly". Geriatrics \& gerontology international, 6(3), 149-158.

Oxorn, H. (2003). Ilmu Kebidanan Patologi dan Fisiologi Persalinan, Jakarta: Yayasan Esensial Medika

Prawirohardjo, Sarwono.2002.Buku Acuan Nasional Pelayanan Kesehatan Maternal Neonatal.Jakarta,JNPKKR_POGI

Rosner, B. 2000. Fundamentals of Biostastistics. Sixth Edition. USA: Harvard Univercity

Rustam, M, 2008. Synopsis Obstetri. Jakarta : EGC

Sandi. 2013. Gambaran Kasus Seksio Sesarea Berdasarkan Status Rujukan di RSU Dokter Soedarso Pontianak Periode 1 Januari-31 Desember 2011, FK Universitas Tanjungpura Pontianak

Sugiyono. 2010. Statistik Untuk Penelitian, Bandung, Alfabeta

Sugiono.2008. Metode Penelitian Kuantitatif Kualitatif. Bandung: Alfabeta

Tamher, S., Noorkasiani. (2009). Kesehatan Usia Lanjut dengan Pendekatan Asuhan Keperawatan.

Wiknjosastro H.2005. Distosia Pada Kelainan Letak Serta Bentuk Janin. Ilmu Kebidanan. Yayasan Bina Pustaka Sarwono Prawirohardjo, Jakarta

Wiknjosastro H. 2007. Ilmu Bedah Kebidanan, Yayasan Bina Pustaka Sarwono Prawirohardjo, Jakarta

Wiradharma 2012. Resiko Asfiksia pada Ketuban Pecah Dini di RSUP Sanglah, Jurnal Bagian Ilmu Kesehatan Anak FKU Udayana RSUP Sanglah. Denpasar.

Yulianti, D. 2005. Buku Saku Manajemen Komplikasi dan Persalinan, Jakarta, EGC. 